\title{
Magnesium sulfate prevents the development of forced swim induced hyperalgesia in rats
}

\author{
Mariana Rada ${ }^{1}$, Ricardo Cárdenas-Fernández², Coram Guevara ${ }^{3}$, Ana Cristina Fernández and \\ Heberto Suárez-Roca ${ }^{2,4}$ \\ ${ }^{1}$ Departamento de Biología, Facultad Experimental de Ciencias, Universidad del Zulia, Maracaibo, \\ Venezuela \\ ${ }^{2}$ Sección de Neurofarmacología y Neurociencias, Instituto de Investigaciones Clínicas "Dr. \\ Américo Negrette", Universidad del Zulia, Maracaibo, Venezuela \\ ${ }^{3}$ Laboratorio de Biología Oral, Instituto de Investigaciones de la Facultad de Odontología, \\ Universidad del Zulia, Maracaibo, Venezuela \\ ${ }^{4}$ Center for Translational Pain Medicine, Dept. of Anesthesiology, Duke University, Durham, NC, \\ USA
}

Keywords: magnesium sulfate; thermal hyperalgesia; forced swim

Abstract. The present study evaluated the effect of magnesium sulfate $\left(\mathrm{MgSO}_{4}\right)$ on forced swim-induced thermal hyperalgesia in male Sprague-Dawley rats. Two schemes of $\mathrm{MgSO}_{4}$ administration were used: a preemptive scheme $(100 \mathrm{mg} / \mathrm{kg}$ i.p. before each forced swim) and a therapeutic scheme (a single dose of $100 \mathrm{mg} / \mathrm{kg}, 24$ hours after the final forced swim); pharmacological controls received normal saline. Thermal nociception was determined using the hot plate test, and lumbar spinal levels of nitric oxide (NO) metabolites were measured. Thermal hyperalgesia was present in forced swim animals treated with saline before each forced swim, but absent in forced swim animals preemptively treated with $\mathrm{MgSO}_{4} . \mathrm{We}$ could not determine an anti-hyperalgesic effect of the therapeutic scheme since $\mathrm{MgSO}_{4}$ tended to produce analgesia when administered one hour before the hot plate test, probably due to an acute stress response caused by the injection. On the other hand, non-stressed animals preemptively treated with $\mathrm{MgSO}_{4}$ displayed significantly higher levels of NO metabolites than forced swim animals preemptively treated with $\mathrm{MgSO}_{4}$ or saline and non-stressed animals preemptively treated with saline. The results suggest that $\mathrm{MgSO}_{4}$ can prevent the development of persistent pain states, but is unable to revert already established ones, a potential feature in patients suffering from anxiety, depression and chronic stress exposure; likewise, they indicate that the effect of $\mathrm{MgSO}_{4}$ on nociception is independent of an induction of $\mathrm{NO}$ synthesis.

Corresponding author: Ricardo Cárdenas-Fernández. Sección de Neurofarmacología y Neurociencias, Instituto de Investigaciones Clínicas “Dr. Américo Negrette”, Universidad del Zulia Maracaibo, Venezuela. Email: ricardojosecardenas@ gmail.com 


\section{Sulfato de magnesio previene el desarrollo de hiperalgesia inducida por nado forzado en ratas}

Invest Clin 2018; 59(1): 5-16

Palabras claves: sulfato de magnesio; hiperalgesia térmica; nado forzado

Resumen. El presente estudio evaluó el efecto del sulfato de magnesio $\left(\mathrm{MgSO}_{4}\right)$ sobre la hiperalgesia térmica inducida por nado forzado en ratas macho Sprague-Dawley. Se utilizaron dos esquemas de administración de $\mathrm{MgSO}_{4}$ : un esquema preventivo (100 mg/kg i.p., antes de cada nado forzado) y un esquema terapéutico (una dosis única de $100 \mathrm{mg} / \mathrm{kg}$ i.p., 24 horas luego de la última sesión de nado); los controles farmacológicos recibieron solución salina fisiológica. Se determinó la nocicepción térmica mediante la prueba de plato caliente y se midieron los valores de metabolitos de oxido nítrico (NO) en médula espinal. Se observó hiperalgesia térmica en animales sometidos a nado forzado tratados con solución salina antes de cada sesión de nado, pero estuvo ausente en animales previamente tratados con $\mathrm{MgSO}_{4}$. No pudimos determinar un efecto anti-hiperalgésico en el esquema de administración terapéutico puesto que el $\mathrm{MgSO}_{4}$ tendió a producir analgesia al administrarlo una hora antes del plato caliente, probablemente debido a un efecto de estrés agudo causado por la inyección. Por otro lado, los animales no estresados tratados preventivamente con $\mathrm{MgSO}_{4}$ mostraron niveles significativamente más elevados de metabolitos de NO en médula espinal al compararlos con los animales sometidos a nado forzado pretratados con $\mathrm{MgSO}_{4}$ o salina y con los animales no estresados pretratados con salina. Estos resultados sugieren que el $\mathrm{MgSO}_{4}$ puede prevenir el desarrollo de estados de dolor persistente, pero no revertir los estados ya establecidos, un rasgo potencial en pacientes que sufren de ansiedad, depresión y en pacientes expuestos a estrés crónico; igualmente, indican que el efecto del $\mathrm{MgSO}_{4}$ sobre la nocicepción es independiente de su efectosobre la síntesis de NO.

Recibido: 07-11-2016 Aceptado: 08-02-2018 


\section{INTRODUCTION}

Magnesium sulfate has been studied as an analgesic agent, both as monotherapy or in multimodal analgesia (1-3). The proposed mechanism for the antinociceptive effect of magnesium involves inhibition of glutamatergic activity through blockade of the NMDA receptor (4), as well as inhibition of cellular calcium influx via modulation of L-type calcium channels, thus diminishing cell excitability (5). $\mathrm{MgSO}_{4}$ has also been demonstrated to directly inhibit the release of glutamate in the central nervous system (6). The activation of the NMDA receptor via glutamate is a crucial step in nociception, especially in the context of chronic pain states (7); likewise, activation of the NMDA receptor leads to increased production of nitric oxide (NO), a gaseous neurotransmitter which participates in the inflammatory response and is involved in persistent pain states $(8,9)$. In clinical studies, magnesium has been shown to exert beneficial effects in the management of pain, particularly in post-surgical pain $(10,11)$.

Although generally considered as an analgesic or adjuvant, however, some studies have reported an opposite effect of magnesium: thus, intravenous administration of $\mathrm{MgSO}_{4}$ in local capsaicin-induced thermal hyperalgesia has been demonstrated to increase pain intensity (12). Similarly, in an animal model of mechanical hyperalgesia, hind paw administration of $\mathrm{MgSO}_{4}$ induced mechanical hyperalgesia, which was dependent on NO production (13). Even in the clinical setting, not all research groups report analgesic effects when administering $\mathrm{MgSO}_{4}$ (14).

We have previously shown that enhanced glutamate transmission, as well as an increase in glutamate-dependent $\mathrm{NO}$ production, participate in the development of cutaneous hyperalgesia in rats exposed to repeated swim stress (15). Considering the fact that magnesium acts as a physiological NMDA receptor antagonist, thus potentially preventing excessive glutamatergic transmission, while also blocking the increase in NO production, the aim of the present study was to evaluate the effect of magnesium sulfate on thermal hyperalgesia in rats exposed to repeated forced swim stress. The ion, with its pharmacological safety margin and relative lack of side effects, could be useful in the management of several chronic pain disorders in which persistent psychophysical stress plays a role.

\section{ANIMALS AND EXPERIMENTAL PROTOCOL}

Male Sprague Dawley rats, weighing 150300 grams, 8-10 weeks old (Vivarium, Faculty of Veterinary Sciences, LUZ), were used in the study. Animals were kept in individual cages, with food and water available ad libitum. Room temperature was kept at $24-26^{\circ} \mathrm{C}$, with hourly changes in room air, regulated humidity and a 12-hour light/dark cycle. Experiments were performed during the light period.

Fig. 1 summarizes the experimental design. Forced swim animals were placed inside a Plexiglas ${ }^{\circledR}$ cylinder $(30 \mathrm{~cm}$ diameter, $50 \mathrm{~cm}$ height) filled with water at $24-26{ }^{\circ} \mathrm{C}$, with a volume sufficient to ensure complete submersion of the rat (except for its head), preventing the tail from supporting the weight of the body. Rats were subjected to three consecutive sessions: a 10-min session on day 1 , and a $20-$ min session on days 2 and 3 of the experimental design. Rats were allowed to get dry in a warm environment $\left(30-32{ }^{\circ} \mathrm{C}\right)$ after each swimming session. The cylinder was thoroughly cleaned before each swimming session, for each animal. Non-conditioned animals remained undisturbed in their cages during days 1,2 and 3 of the experimental design, except for the minimally necessary manipulation inherent to the hot-plate

Vol. 59(1): 5-16, 2018 
tests and the administration of either the drug or the vehicle.

Thermal nociception was assessed by placing the animal on a hot plate (IITC, model $39 \mathrm{D}, \mathrm{USA})$ at $52.5^{\circ} \mathrm{C}\left( \pm 0.5^{\circ} \mathrm{C}\right)$. The time lapse (latency) between the placing of the animal on the plate and the manifestation of nociceptive behavior (licking or biting of either hindpaw or jumping on all four limbs) was recorded in seconds. A cut-off time of $45 \mathrm{~s}$ was established in order to avoid burning of the paws. Two measurements were performed: a baseline thermal nociception measurement (pre- $\mathrm{MgSO}_{4}$ for groups $\mathrm{A}$ and $\mathrm{C}$; pre-saline for groups $\mathrm{B}$ and D; pre-first swim for groups A, B, E and F), on day 1 of the experimental design; and a second measurement (post-MgSO 4 for groups $\mathrm{E}$ and $\mathrm{G}$; post-saline for groups $\mathrm{F}$ and $\mathrm{H} ; 24$ hour postlast swim for groups A, B, E and F), on day 4 of the experimental design; no measurements were performed on days 2 or 3 . The two measurements allowed to determine whether or not any changes in the thermal nociceptive threshold had occurred. Observers were unaware of both the behavioral protocol and the pharmacological treatment of the animal.

According to drug administration regime, animals were divided into two main groups, as follows: a preemptive scheme, treated with $\mathrm{MgSO}_{4}$ on days 1, 2 and 3 of the experimental design before each forced swim, to determine if $\mathrm{MgSO}_{4}$ exerted a preemptive effect on thermal hyperalgesia induced by repeated forced swim (thus, animals in this group received a total of

\begin{tabular}{|l|l|l|l|l|}
\hline Group A & Group A & Group A & Group A & \\
HP1, MgSO4, FS & MgSO4, FS & MgSO4, FS & HP2 & \\
Group B & Group B & Group B & Group B & \\
HP1, Saline, FS & Saline, FS & Saline, FS & HP2 & \\
Group C & Group C & Group C & Group C & \\
HP1, MgSO 4, NS & MgSO4, NS & MgSO4, NS & HP2 & \\
Group D & Group D & Group D & Group D & All groups \\
HP1, Saline, NS & Saline, NS & Saline, NS & HP2 & Sacrifice \\
Group E & Group E & Group E & Group E & \\
HP1, FS & FS & FS & MgSO4, HP2 & \\
Group F & Group F & Group F & Group F & \\
HP1, FS & FS & FS & Saline, HP2 & \\
Group G & Group G & Group G & Group G & \\
HP1, NS & NS & NS & MgSO4, HP2 & \\
Group H & Group H & Group H & Group H & \\
HP1, NS & NS & NS & Saline, HP2 & \\
\hline Day 1 & Day 2 & Day 3 & Day 4 & Day 5 \\
\hline
\end{tabular}

Fig. 1. Experimental design. HP1: baseline thermal nociception measurement; MgSO4: injection with magnesium sulfate; FS: forced swim; Saline: injection with normal saline; NS: non-stressed animals; HP2: second thermal nociception measurement. Groups A, B, C, and D belonged to the preemptive scheme; groups E, F, G and $\mathrm{H}$ belonged to the therapeutic scheme. On day 1, HP1 was performed one hour before MgSO4 injection for groups $\mathrm{A}$ and $\mathrm{C}, 1$ hour before saline injection for groups $\mathrm{B}$ and $\mathrm{D}$, and two hours before the first swim session for groups $\mathrm{E}$ and $\mathrm{F}$. On days 2 and 3, $\mathrm{MgSO} 4$ and saline were injected one hour before $\mathrm{FS}$ for groups $\mathrm{A}$ and $\mathrm{B}$, respectively. On day 4, HP2 was performed one hour after $\mathrm{MgSO} 4$ injection for groups $\mathrm{E}$ and $\mathrm{G}$, and one hour after saline injection for groups $\mathrm{F}$ and $\mathrm{H}$. All animals were sacrificed on day 5. 
three injections); and a therapeutic scheme, treated with only one dose of $\mathrm{MgSO}_{4}$ before the second hot plate test (day 4 of the experimental design), to determine if a single dose of $\mathrm{MgSO}_{4}$, administered after the exposure to stress, could revert an established thermal hyperalgesia; the second hot plate test (day 4 of the experimental design) was compared with the first hot plate test (day 1 of the experimental design) to determine the presence or absence of thermal hyperalgesia. In both administration schemes, $\mathrm{MgSO}_{4}$ was injected at a dose of $100 \mathrm{mg} / \mathrm{kg}$ i.p., dissolved in normal saline. Animals injected with vehicle (normal saline solution, $100 \mu \mathrm{L}$ i.p.) served as pharmacological controls. Each subgroup consisted of at least 5 animals.

\section{Lumbar spinal cord extraction and NO metabolite detection}

On day 5 of the experimental design, animals were euthanized with i.p. xylacine and ketamine, and intracardially perfused with cold PBS. Subsequently, the lumbar segment of the spinal cord was surgically exposed, extracted and homogenized in 10 volumes of $50 \mathrm{mmol} / \mathrm{L}$ tris-buffer (pH: 7.4), with $1 \mathrm{mmol} / \mathrm{L}$ EDTA, 1 $\mathrm{mmol} / \mathrm{L} \mathrm{NaCl}, 1 \mathrm{lg} / \mathrm{mL}$ aprotinin-isopropanol, and $100 \mu \mathrm{g} / \mathrm{mL}$ phenylmethylsulfonyl fluoride (PMSF) (Sigma Chemical Co., St. Louis, MO). Homogenates were centrifuged at $7000 \mathrm{~g}$ for 20 minutes at $4^{\circ} \mathrm{C}$. Supernatant was collected, and the content of nitrates (NO4) and nitrites (NO3) was determined via a two-step process using a commercially available colorimetric kit (Nitric Oxide Assay Kit,Thermo Fisher Scientific, USA). 1:25 diluted homogenate samples were evaluated via the two-step reaction: the first step transforms nitrate into nitrite through nitrate reductase, and a second step transforms nitrite into an azoate compound, via the Griess reagent. The reaction color intensity was measured by spectrophotometry at $\lambda=540 \mathrm{~nm}$.
The quantity of a cochromophore reflects the concentration of NO (16).

\section{Bioethical considerations}

Animals were handled according to the guidelines of the Society for Neuroscience and the International Association for the Study of Pain (IASP) on the handling of laboratory animals. The experimental design was evaluated and approved by the technical council of the Institute of Clinical Research "Dr. Américo Negrette".

\section{Statistical analysis}

The Kolmogorov-Smirnoff test was applied to determine whether data followed a normal distribution. Student's t test was used to compare the first and second hot plate tests. One-way ANOVA followed by Tukey's multiple comparison test was used to compare nitrite metabolite levels in all the groups. Results were expressed as the mean \pm standard deviation (SD). Differences between groups were considered statistically significant if $\mathrm{p}<0.05$.

\section{RESULTS}

\section{Effect of $\mathrm{MgSO}_{4}$ on hot-plate latency}

Animals injected with $\mathrm{MgSO}_{4}$ before each forced swim, did not display a statistically significant decrease in the post-stress hot plate test latency when compared to the pre-stress measurement (Fig. 2A).

In contrast, forced swim animals injected with saline before the exposure to the stressor, showed a decrease in the thermal nociceptive threshold, expressed as a statistically significant decrease in hot-plate latency in the post-stress hot-plate measurement when compared to the pre-stress thermal nociception (Fig. 2B).

The administration of either $\mathrm{MgSO}_{4}$ or saline to non-stressed animals had no effect on hot plate response latencies (Figs. 2C and 2D). 

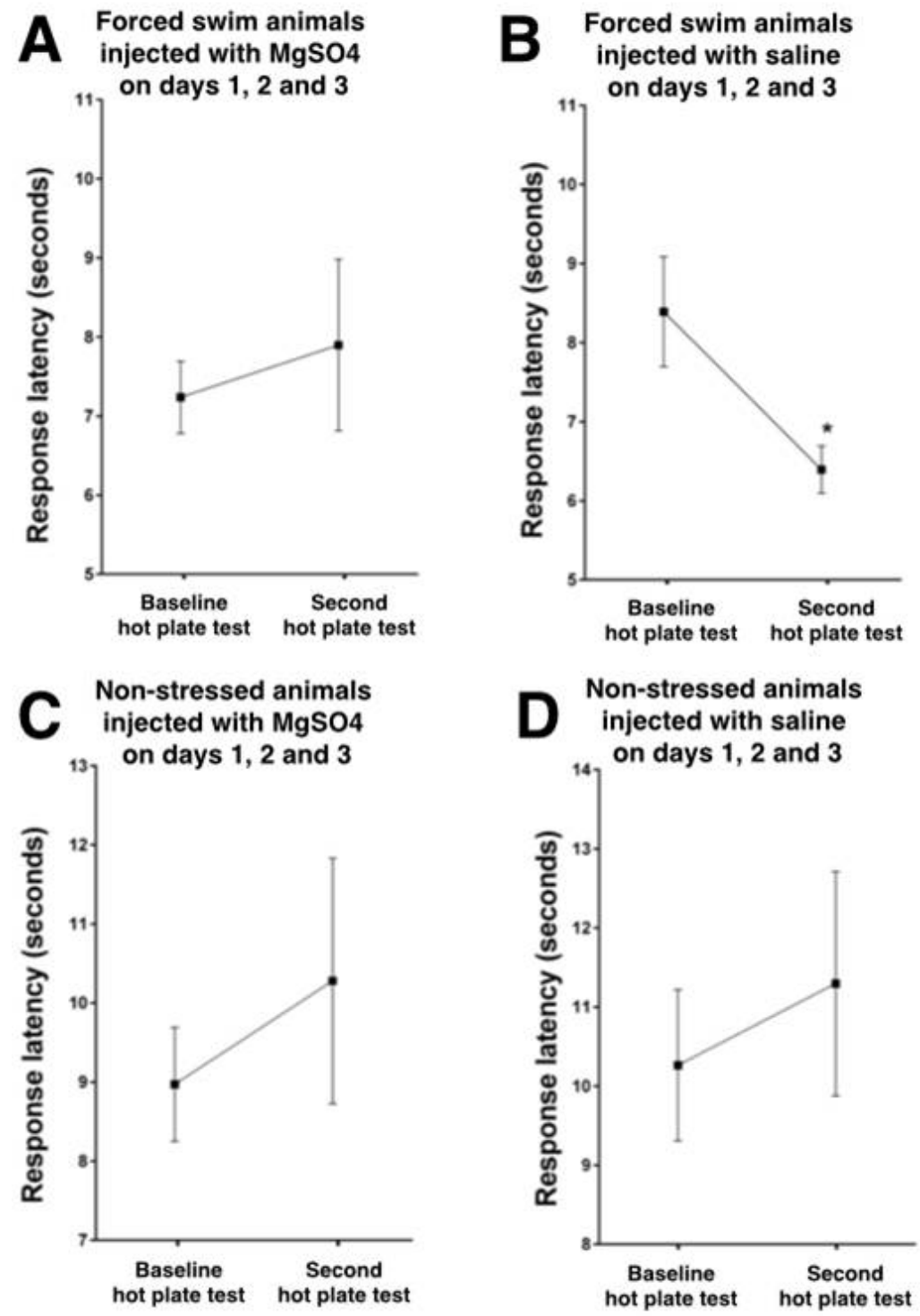

Fig. 2. $\mathrm{MgSO} 4$ prevents the development of forcedswim stress-induced thermal hyperalgesia in the preemptive scheme. For all four panels: on the ordinate, response latency, in seconds, from the start of the test until the manifestation of pain-associated behavior; on the abscissa, baseline and second hot plate tests (respectively, day 1 and day 4 of the experimental design). Results shown as mean +/- SD. No statistically significant differences were observed between the two measurements in panels A, C, or D. On panel B: *= statistically significant difference between the baseline and second hot plate test (Student's $\mathrm{t}$ test, $\mathrm{p}=0.0219$ ). 
No statistically significant differences were observed for the hot plate latencies in the therapeutic scheme (Fig. 3), although a nonsignificant increase in hot plate response latency was observed in non-stressed animals injected with $\mathrm{MgSO}_{4}$ on day 4 of the experimental design, before the post-stress hot-plate test (Fig. $3 \mathrm{C})$.

\section{Effect of $\mathrm{MgSO}_{4}$ on NO metabolites}

Lumbar spinal levels of NO metabolites in non-stressed animals injected with $\mathrm{MgSO}_{4}$ on days 1, 2 and 3 of the experimental design were significantly higher than those of the other groups (Fig. 4A).
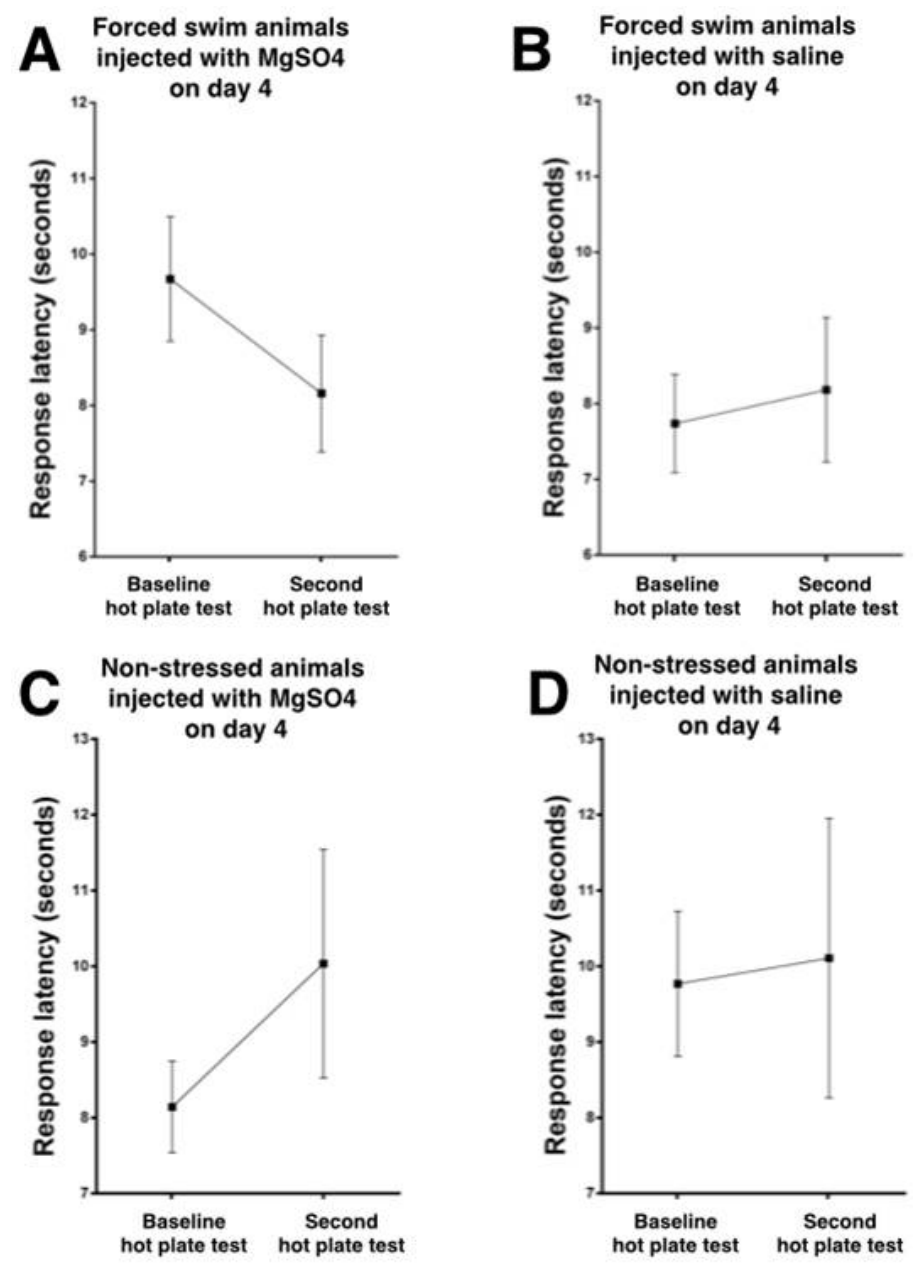

Fig.3. Effect of the therapeutic scheme of magnesium administration on thermal nociception. For all four panels: on the ordinate, response latency, in seconds, from the start of the test until the manifestation of pain-associated behavior; on the abscissa, baseline and second hot-plate measurements (respectively, day 1 and day 4 of the experimental design). Results shown as mean $+/$ - SD. No statistically significant differences were evidenced between the two measurements in any of the groups .

Vol. 59(1): 5-16, 2018 


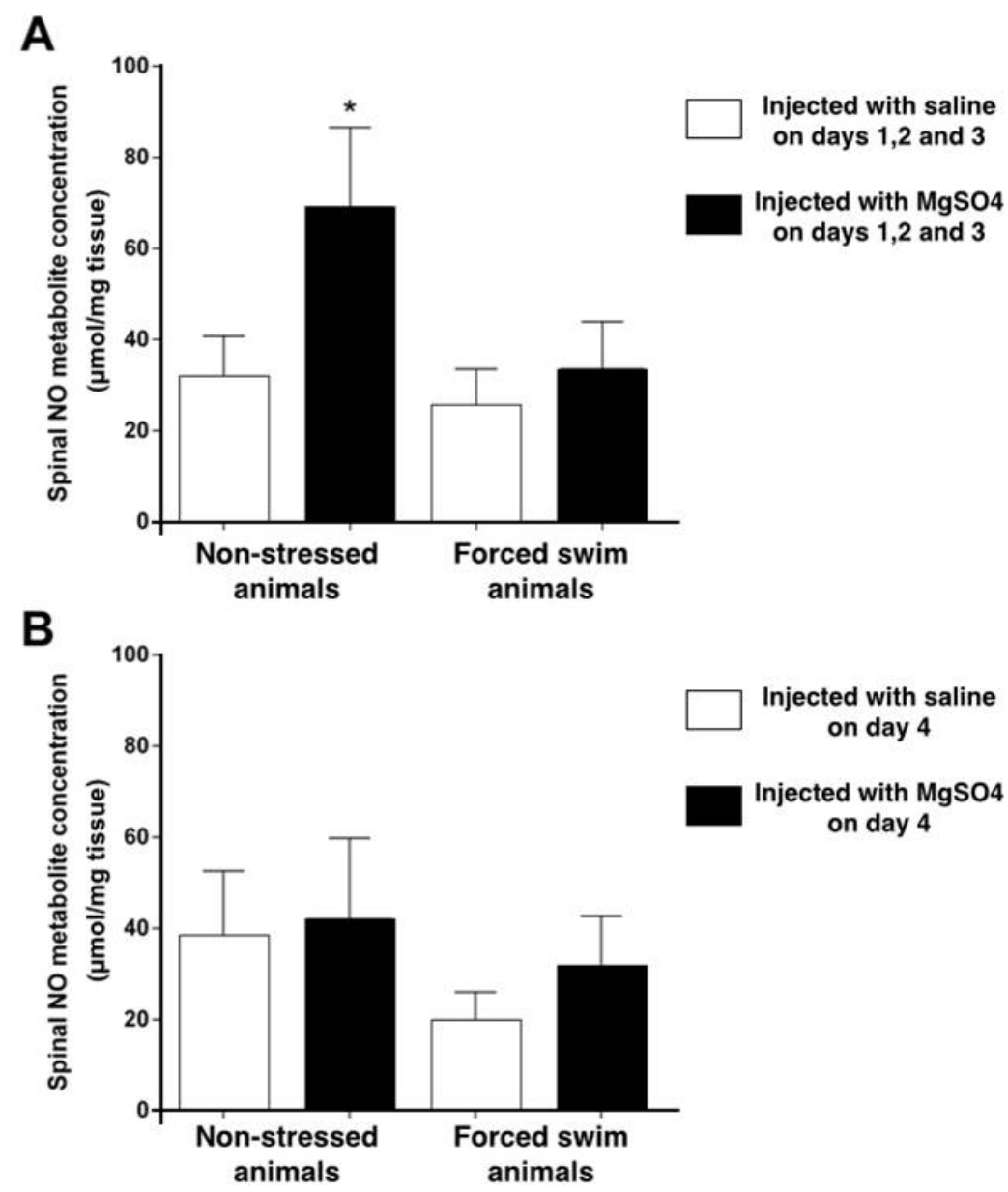

Fig.4. Concentration of NO metabolites in the lumbar spinal cord. For both panels: on the ordinate, spinal NO metabolite concentration in $\mu \mathrm{mol} / \mathrm{mg}$ of tissue; on the abscissa, experimental groups. Results shown as mean $+/$ - SD. Panel A, preemptive scheme. $*=$ statistically significant difference when compared to the other three groups (one-way ANOVA followed by Tukey's multiple comparison test, $\mathrm{p}=0,012$ ). Panel $\mathrm{B}$, therapeutic scheme. No statistically significant differences between groups were observed in this scheme.

No statistically significant difference was evidenced in $\mathrm{NO}$ metabolites between groups in the therapeutic scheme (Fig. 4B).

\section{DISCUSSION}

\section{Thermal nociception and $\mathrm{MgSO}_{4}$}

Our results suggest that $\mathrm{MgSO}_{4}$ prevents the initiation and development of thermal hyperalgesia when administered before the exposure to stress. This is an effect comparable to the one we previously reported with ketoprofen and meloxicam (16). $\mathrm{MgSO}_{4}$ has been shown to exert anti-hyperalgesic effects in models of neuropathic pain and diabetic peripheral mononeuropathy in rats (18-20), and in animal models of magnesium deficiency, where $\mathrm{MgSO}_{4}$ can be anti-hyperalgesic at low 
doses and analgesic at high doses (21). On the other hand, forced swim animals injected with saline before each forced swim, developed thermal hyperalgesia, as we have previously reported (16). Forced swim induces changes in the release of glutamate and GABA, with an increase in the former and a decrease in the latter, creating a pro-hyperalgesic environment in the spinal cord $(15,17)$. $\mathrm{MgSO}_{4}$, administered before each forced swim, could have prevented the overactivation of the NMDA receptor.

Besides NMDA inhibition, $\mathrm{MgSO}_{4}$ has been shown to act upon several other cellular processes, especially calcium influx, acting on the L-type voltage gated calcium channel, as well as modulating sodium and potassium currents, which indicates a global effect on membrane potential (23). Additionally, it inhibits the release of glutamate and aspartate when administered intrathecally $(24,25)$, and prevents nuclear translocation of NF-kB from the cytoplasm in cultured microglia (26). In this regard, hypomagnesemia in rats is associated with increased plasma levels of substance P, a neuropeptide known to play a key role in nociception (27).

Forced swim animals injected with saline before the second hot plate test (day 4 of the experimental design), did not develop the expected thermal hyperalgesia. It is possible that the injection procedure induced an analgesic effect associated with acute stress, as has been previously reported (28). According to Zalman and Galina (29), acute stress analgesia is mediated by opioid and non-opioid mechanisms in the peripheral and central nervous system (16, 30). Since this group did not develop thermal hyperalgesia, it was not possible to determine if $\mathrm{MgSO}_{4}$ had an anti-hyperalgesic effect.

In non-stressed animals injected with $\mathrm{MgSO}_{4}$ on day 4 of the experimental design, before the second hot plate test, $\mathrm{MgSO}_{4}$ might have had a weak (subthreshold) analgesic effect. In agreement, $\mathrm{MgSO}_{4}$ is considered as an adjuvant to other analgesics, diminishing the doses needed to obtain analgesia with classic agents (22). Under some conditions, $\mathrm{MgSO}_{4}$ could have a more evident analgesia. In a study using magnesium-deficient rats, $\mathrm{MgSO}_{4}$ exerted a direct analgesic effect (21). Moreover, $\mathrm{MgSO}_{4}$ showed an antinociceptive effect in the acetic acid writhing test, a model of visceral pain in animals (23).

$\mathrm{MgSO}_{4}$, however, has also been shown to induce hyperalgesia after local and systemic administration, in both animals and humans (12, 13). Thus, $\mathrm{MgSO}_{4}$ has a more complex behavior than originally thought, and additional factors involved in determining its effect on nociception should be thoroughly studied in the future.

\section{Spinal nitric oxide and $\mathrm{MgSO}_{4}$}

The repeated administration of $\mathrm{MgSO}_{4}$ to non-stressed animals increased the spinal concentration of NO metabolites (Fig. 4A). Under some experimental conditions $\mathrm{MgSO}_{4}$ could be involved in increased NO synthesis, and as a result induce hyperalgesia (instead of analgesia). For example, in a model of peripheral mechanical hyperalgesia, the intraplantar injection of $\mathrm{MgSO}_{4}$ in the hind paw of Wistar rats induced mechanical hyperalgesia by a mechanism that can be blocked by the administration of an NMDA receptor antagonist (MK-801) or a non-selective NO synthase inhibitor (L-NAME) (13). In the present study, however, non-stressed rats treated with $\mathrm{MgSO}_{4}$ did not display hyperalgesia but showed increased concentrations of NO. Thus, the inhibitory effect of $\mathrm{MgSO}_{4}$ on the stress-induced hyperalgesia could be separate from its effect on NO synthesis.

In conclusion, our findings suggest that $\mathrm{MgSO}_{4}$ has an anti-hyperalgesic actitvity by a mechanism independent of $\mathrm{NO} . \mathrm{MgSO}_{4}$ could be useful in clinical situations where 
psychophysical stress is associated with persistent pain.

\section{REFERENCES}

1. Radwan YA, Alfeky AA, Faramawi MF. Analgesic effect of intra-articular magnesium sulphate compared with bupivacaine after knee arthroscopic menisectomy. J Adv Res 2013; 4:355-360

2. Mirkheshti A, Aryani MR, Shojaei P, Dabbagh A. The effect of adding magnesium sulfate to lidocaine compared with paracetamol in prevention of acute pain in hand surgery patients under intravenous regional anesthesia (IVRA). Int J Prev Med 2012; 3(9): 616-621

3. SavicVujovic KR, Vuckovic S, Srebro D, Medic B, Stojanovic R, Vucetic C, Prostran M. A synergistic interaction between magnesium sulphate and ketamine on the inhibition of acute nociception in rats. Eur Rev Med Pharmacol Sci 2015; 19: 2503-2509

4. Fawcett WJ, Haxby EJ, Male DA. Magnesium: physiology and pharmacology. Br J Anaesth 1999; 83: 302-320

5. Lin CY, Tsai PS, Hung YC, Huang CJ. L-type calcium channels are involved in mediating the anti-inflammatory effects of magnesium sulphate. Br J Anaesth 2010; 104 (1): 44-51

6. de Baaij JHE, Hoenderop JGJ, Bindels RJM. Magnesium in man: implications for health and disease. Physiol Rev 2015; 95 (1): $1-46$.

7. Yan X, Jiang E, Gao M, Weng HR. Endogenous activation of presynaptic NMDA receptors enhances glutamate release from the primary afferents in the spinal dorsal horn in a rat model of neuropathic pain. J Physiol 2013; 591(7):2001-2019.

8. Srebro DP, VuckovićSM, SavicVujovic KR, Prostran MS. Nitric oxide synthase modulates the antihyperalgesic effect of the NMDA receptor antagonist MK-801 on carrageenan-induced inflammatory pain in rats. Tohoku J Exp Med 2014; 234(4):287293.

9. Mukherjee P, Cinelli MA, Kang S, Silverman RB. Development of nitric oxide synthase inhibitors for neurodegeneration and neuropathic pain. Chem Soc Rev 2014; 43(19): 6814-6838.

10. Kundra S, Singh RM, Singh G, Singh T, Jarewal V, Katyal S. Efficacy of magnesium sulphate as an adjunct to ropivacaine in local infiltration for postoperative pain following lower segment caesarean section. J ClinDiagn Res 2016; 10(4):UC18-22. doi: 10.7860/JCDR/2016/17119.7683.

11. Shah PN, Dhengle Y. Magnesium sulfate for postoperative analgesia after surgery under spinal anesthesia. Acta Anaesthesiol Taiwan 2016; 54(2):62-4. doi: 10.1016/j. aat.2016.06.003.

12. Mikkelsen S, Dirks J, Fabricius $P$, Petersen KL, Rowbotham MC, Dahl JB. Effect of intravenous magnesium on pain and secondary hyperalgesia associated with the heat/capsaicin sensitization model in healthy volunteers. Br J Anaesth 2001; 86(6):871-873.

13. Srebro DP, Vučković SM, Savić Vujović KR, Prostran MS. TRPA1, NMDA receptors and nitric oxide mediate mechanical hyperalgesia induced by local injection of magnesium sulfate into the rat 
hind paw. Physiol Behav 2015; 139: 267273

14. Ghaffaripour S, Mahmoudi H, Eghbal H, Rahimi A. The effect of intravenous magnesium sulfate on post-operative analgesia during laminectomy. Cureus 2016; 8(6):e626. doi: 10.7759/cureus.626.

15. Quintero L, Cardenas R, Suarez-Roca $H$. Stress-induced hyperalgesia is associated with a reduced and delayed GABA inhibitory control that enhances post-synaptic NMDA receptor activation in the spinal cord. Pain 2011; 152: 1909-1922.

16. Guevara C, Fernandez AC, Cardenas R, Suarez-Roca H. Reduction of spinal PGE2 concentrations prevents swim stressinduced thermal hyperalgesia. Neurosci Lett 2015; 591: 110-114.

17. Suarez-Roca H, Leal L, Silva JA, PineruaShuhaibar L, Quintero L. Reduced GABA neurotransmission underlies hyperalgesia induced by repeated forced swimming stress. Behav Brain Res 2008; 189(1): 159-169.

18. Xiao W, Bennet G. Magnesium suppresses neuropathic pain responses in rats via a spinal site of action. Brain Research 1994; 666(2):168-172.

19. Demirkaya S, Vural O, Dora B, Topçuoğlu M. Efficacy of intravenous magnesium sulfate in the treatment of acute migraine attacks. Headache 2001; 41(2):171-177.

20. Begon S, Pickering G, Eschalier A, Dubray C. Magnesium increases morphine analgesic effect in different experimental models of pain. Anesthesiology 2002; 96 (3): 627-632.

21. Begon S, Pickering G, Eschalier A, Mazur A, Rayssiguier Y, Dubray C. Role of spinal NMDA receptors, protein kinase $\mathrm{C}$ and nitric oxide synthase in the hyperalgesia induced by magnesium deficiency in rats. $\mathrm{Br}$ J Pharmacol 2001; 134: 1227-1236.

22. Sang-Hwan D. Magnesium: a versatile drug for anesthesiologists. Korean $\mathrm{J}$ Anesthesiol 2013; 65(1): 4-8.

23. Vuckovic S, Srebro D, SavicVujovic K, Prostran M. The antinociceptive effects of magnesium sulfate and MK-801 in visceral inflammatory pain model: The role of $\mathrm{NO} /$ cGMP/K+ ATP pathway. Pharm Biol 2015; 53(11):1621-1627.

24. Tsai PS, Cheng JK, Marsala M, Lin CR, Wen GH, Yang LC. Intrathecal magnesium sulfate attenuates algogenic behavior and spinal amino acids release after kainic acid receptor activation in rats. Neurosci Lett 2001; 301(2):115-118.

25. Kang SW, Choi SK, Park E, Chae SJ, Choi S, JinJoo H, Lee GJ, Park HK. Neuroprotective effects of magnesiumsulfate on ischemic injury mediated by modulating the release of glutamate and reduced of hyperreperfusion. Brain Res 2011; 1371:121-128.

26. Gao F, Ding B, Zhou L, Gao X, Guo H, Xu H. Magnesium sulfate provides neuroprotection in lipopolysaccharideactivated primary microglia by inhibiting NF- $\kappa$ B pathway. J Surg Res 2013; 184(2):944-950.

27. Weglicki WB, Chmielinska JJ, TejeroTaldo I, Kramer JH, Spurney CF, Viswalingham K, Lu B, Mak IT. Neutral endopeptidase inhibition enhances substance $\mathrm{P}$ mediated inflammation due to hypomagnesemia. Magnes Res 2009; 22(3):167S-173S.

28. Olango W, Finn D. Neurobiology of 
stress-induced hyperalgesia. Curr Top BehavNeurosci 2014; 20:251-280.

29. Zalman A, Galina H. Stress-induced analgesia: adaptive pain suppression. Physiol Rev 1986; 66(4): 1091-1114.

30. Hohman A, Suplita R, Bolton N, Neely M, Fegley D, Mangieri R, Krey J, Walker M, Holmes P, Crystal J, Duranti A, Tontini A, Mor M, Tarzia G, Piomelli P. An endocannabinoid mechanism for stress induced analgesia. Nature 2005; 435(23): 1108-1112. 